\title{
Energy Optimization of Ship's Shaft Generator with Permanent Magnet Synchronous Generator
}

\section{Energetska optimizacija brodskog osovinskog generatora sa sinkronim generatorom s permanentnim magnetima}

\author{
Sergey German-Galkin \\ Institute of Marine Electrical Engineering \\ and Automation \\ Maritime University \\ Szczecin, Poland \\ e-mail: s.german-galkin@am.szczecin.pl \\ Dariusz Tarnapowicz \\ Institute of Marine Electrical Engineering \\ and Automation \\ Maritime University \\ e-mail:D.Tarnapowicz@am.szczecin.pl
}

\begin{abstract}
Summary
With the development of power electronic systems, the use of a shaft generator in ship power plant systems is becoming more widespread. The use of the Permanent Magnet Synchronous Generator (PMSG) in these systems instead of the commonly used Electrically Excited Synchronous Generator (EESG) results in increased propulsion efficiency and reliability of the ship's power plant. The lack of a voltage regulator in PMSG requires the use of an electronic power converter to maintain constant voltage parameters in the ship's network, consisting of an active rectifier (AR) and an active network inverter (Al). The article presents AR tests in the PMAG-AR system, whose task is to maintain a constant voltage of the DC circuit when the shaft speed and load changes, as a result of which the selection of Al remains a simple choice. Energy optimization of the shaft generator system was also carried out, which allows reducing losses in AR and PMSG by limiting reactive power in the PMSG-AR system, which is particularly important in high power plants.
\end{abstract}

\section{Sažetak}

Razvojem sustava energetske elektronike, uporaba osovinskog generatora u sustavima brodskih energetskih postrojenja postaje sve raširenija. Primjena sinkronog generatora s permanentnim magnetima (PMSG) u tim sustavima, umjesto najčešće korištenog sinkronog generatora s električnom uzbudom (EESG), dovodi do povećane pogonske učinkovitosti i pouzdanosti brodskog energetskog postrojenja. Nedostatak regulatora napona u PMSG-u zahtijeva uporabu elektroničkog pretvarača za održavanje konstantnih parametara napona u brodskoj mreži, a sastoji se od aktivnog ispravljača (AR) i aktivnog mrežnog pretvarača (Al). U članku su prikazani AR testovi u PMAG-AR sustavu, čiji je zadatak održavati konstantan napon kruga istosmjerne struje kada se mijenja brzina osovine i opterećenja, te kao rezultat toga Al ostaje jednostavan izbor. Izvršena je i energetska optimizacija sustava osovinskog generatora, što omogućava smanjenje gubitaka u AR-u i PMSG-u ograničavanjem jalove snage u sustavu PMSG-AR, a to je posebno važno u postrojenjima velike snage.

\author{
DOI 10.17818/NM/2020/2.6 \\ UDK 621.313 .322 \\ Review / Pregledni rad \\ Paper accepted / Rukopis primljen: 14. 1.2020.
}

\section{KEY WORDS}

shaft generator

permanent magnet synchronous

machine

active rectifier

energy optimization

\section{INTRODUCTION / UVOD}

The ship's power plant is the most important system on the ship, determining the correct operation of the other systems. Economic production of electric energy is important to the economics of ship exploitation.

Shaft generators (SG) have been in use for a long time because they can produce electricity that can cover the energy demand of the entire ship. The use of a shaft generator allows using the reserve power of the main engine of a ship and is therefore the most economical system of an electricity generation on board, while giving up the work of diesel generators (DG).

The main problem of variable shaft speed and variable load has been solved by the evolution of power electronic devices.

The main benefits of using ship's shaft generators can be presented as follows:

energy production using a shaft alternator reduces air pollution, as opposed to other traditional methods of energy production on the ship (e.g. DG). Noise and vibration levels are also reduced,

the use of the SG for electricity production is more costeffective because it does not require expensive fuel, as the main engine is mostly fueled by residual fuel,

the Specific Fuel Oil Consumption (SFOC) for slow-running engines (main engine - ME) is lower than for mediumrunning engines (DG) and the operating point for slowrunning engines is located near the minimum characteristic of SFOC $=f($ Load $)$ (Fig. 1.) [18], 
- the amount of wear and, consequently, the overhaul of Maintenance is reduced for SG,

- the cost of spare parts and the cost of man-hour are low, as the maintenance period of the SG schedule has a higher time interval compared to a DG,

- the installation costs of the shaft generator are also low because they do not require a separate fundament or exhaust system,

- the installation time is shorter for SG,

- low spare parts and man-hour costs, because the maintenance period of the SG schedule has a greater time interval compared to a DG,

- developments in mechanical engineering and the development of semiconductor technologies have allowed engineers to increase the efficiency of ship propulsion by using a generator with PMSG in place of the commonly used EESG.

Developments in mechanical engineering and the development of semiconductor technologies have allowed engineers to increase the efficiency of ship propulsion by using a generator with PMSG in place of the commonly used EESG.

The main advantages of the PMSG compared to the EESG are:

- higher efficiency (over the range of load) (from 3 to 6\% depending on the load [11]),

- easy to obtain a large number of pole pairs, PMSG slow speed) can be installed without gearboxes (loss from the gearbox - about 2\% [11]),

- lower weight and dimensions,

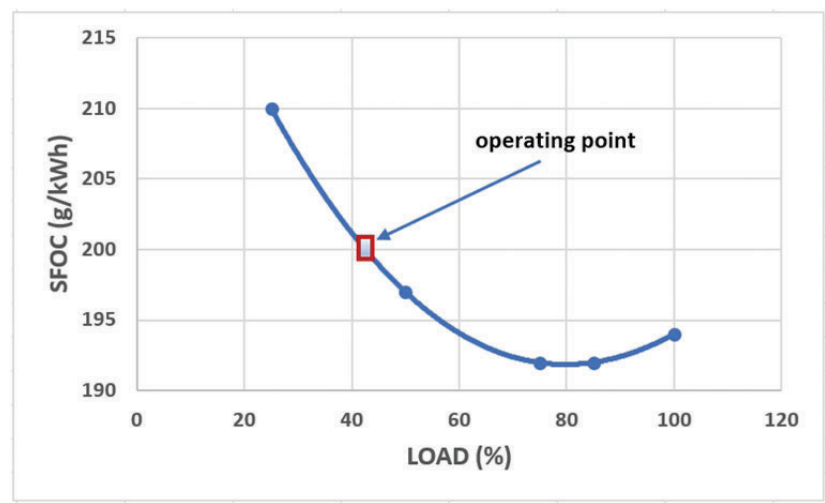

- high operational reliability and simple construction,

- higher power density,

- low vibration level.

In order to eliminate problems with maintaining constant parameters of the voltage generated by the PMSG with the change of the shaft speed and load, it is necessary to use power electronic converters. Figure 2 shows a diagram of the SG system with PMSG, which can be identified:

- ME - Main Engine,

- PMSG- Permanent Magnet Synchronous Generator,

- AR - is an active rectifier,

- ARC - is an active rectifier control system,

- C - DC circuit capacitor.

Generators set with permanent magnet synchronous machine are widely used in the construction of power plants for autonomous objects in hybrid vehicles, wind turbines, aircraft and ship installations $[2,4,15,16]$. In recent years, when building energy systems, more and more preference has been given to DC power grids $[1,5,9,10,14,17]$.

In this article the mechatronic system containing PMSG and active rectifier (AR) is investigated. This system makes it possible to build the DC network in which the direct voltage of the load is supported by AR. Appropriate AR control allows to maintain constant voltage in the DC circuit of the converter together with the change of SG shaft speed and load (within specified limits) [20]. As a consequence, the control of the network inverter is known and simple to implement.

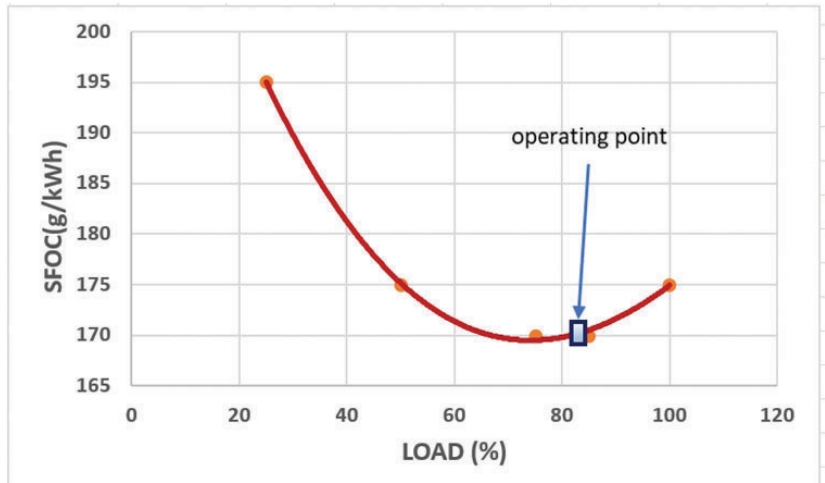

Source: based on [18]

Figure 1 SFOC with load for the DG (a) and the ME+SG (b). Slika 1. SFOC s opterećenjem za DG (a) i ME + SG (b).

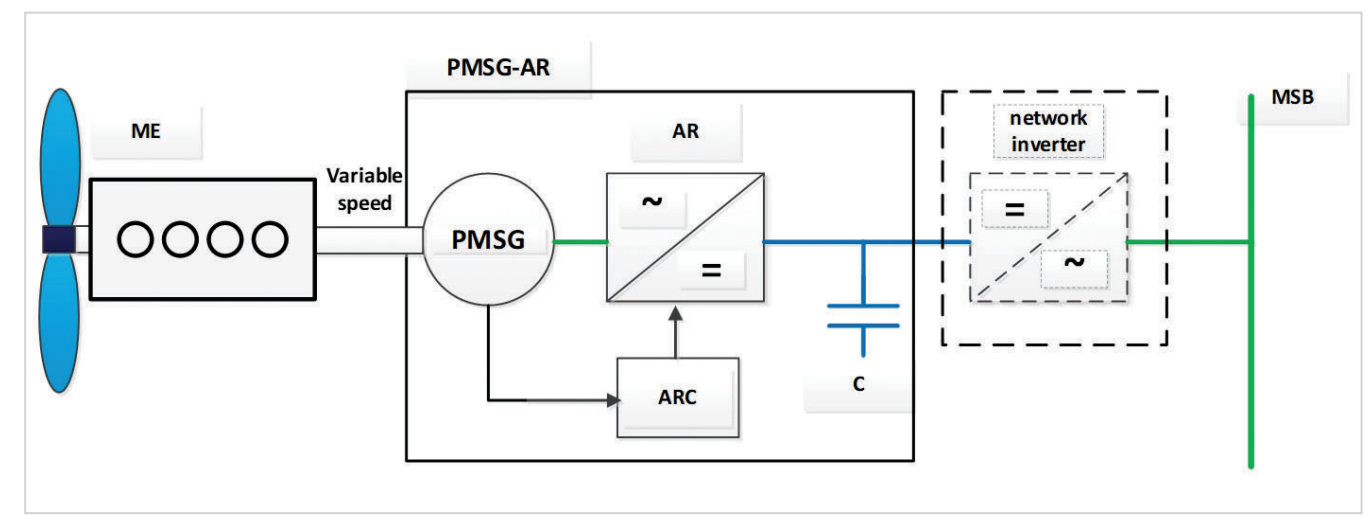

Figure 2. Block diagram of the shaft generator with PMSG

Slika 2. Blok dijagram osovinskog generatora s PMSG-om 


\section{MATHEMATICAL DESCRIPTION OF PMSG / MATEMATIČKI OPIS PMSG-a}

Electromagnetic processes in the system are investigated on the basis of the equivalent scheme. The scheme is presented in Figure 2 [6]. In this equivalent circuit AR is represented by a controlled voltage source $\left(U_{1}\right)$ that is connected in parallel to the stator windings of PMSG with $E_{1}$. The inductive and active resistance in the equivalent circuit are internal parameters of the machine.

The mathematical description of PMSG is carried out in the synchronously rotating coordinate system $(x, y)$ using the generalized (resulting) vector method $[9,12,16]$ and the "main component " method $[3,8]$. This mathematical description looks like:

$$
\bar{E}_{G}(t)=\bar{U}_{1}(t)+L_{1} \frac{d \bar{I}_{1}(t)}{d t}+r_{1} \bar{I}_{1}(t)+j x_{1} \bar{I}_{1}(t)
$$

Where: $\bar{E}_{G}(t)=j \bar{\psi}_{0} \omega(t)$ - spatial vector of electromotive force (emf) on the stator windings;

$\bar{U}_{1}(t)$ - spatial voltage vector in an AC circuit;

$\bar{I}_{1}(t)$ - spatial current vector in the stator windings;

$r_{1}, L_{1}$ - resistance and inductance of machine;

$x_{1}=\omega L_{1}$ - the reactive resistance of the machine;

ù - angular frequency of PSC voltage.

Below we consider the way of controlling the machine, in which the active rectifier acts as a control current source. Similar analysis has been conducted for PMSG with the parameters presented in the Table 1:

Table 1 Parameters of the PMSG Tablica 1. Parametri PMSG- $a$

\begin{tabular}{|l|c|c|c|}
\hline parameters of PMSG & symbol & unit & size \\
\hline nominal phase voltage & $U_{n}$ & $\mathrm{~V}(\mathrm{rms})$ & 220 \\
\hline resistance of armature winding & $r_{s}$ & $\mathrm{~W}$ & 0.05 \\
\hline longitudinal armature induction & $L_{d}$ & $\mathrm{mH}$ & 0.635 \\
\hline longitudinal armature induction & $L_{q}$ & $\mathrm{mH}$ & 0.635 \\
\hline number of pole pairs & $p$ & - & 4 \\
\hline number of phases & $m$ & - & 3 \\
\hline
\end{tabular}

In the rotated coordinate system $d q$ ( $d$ - actual axis, $q$ imaginary axis) equation (1) is presented as:

$$
\begin{aligned}
& 0=U_{d}(t)+L \frac{d I_{d}(t)}{d t}+r_{1} I_{d}(t)-x_{1} I_{q}(t), \\
& E_{1}=E_{q}=U_{q}(t)+L \frac{d I_{q}(t)}{d t}+r_{1} I_{q}(t)+x_{1} I_{d}(t), \\
& U_{d}(t)=\frac{m U_{d c}(t)}{2} \sin \varphi_{m}, \\
& U_{q}(t)=\frac{m U_{d c}(t)}{2} \cos \varphi_{m} .
\end{aligned}
$$

To fully describe the system of equations (2) should be supplemented by the energy balance equation and the Kirchhoff equation in the DC circuit.

$$
\begin{aligned}
& \frac{3}{2} E_{q} I_{q}(t)=U_{d c}(t) \cdot I_{d c}(t)+\frac{3}{2} r_{1}\left(I_{d}^{2}(t)+I_{q}^{2}(t)\right), \\
& C \frac{d U_{d c}(t)}{d t}=I_{d c}(t)-I_{L}(t)=I_{d c}(t)-\frac{U_{d c}(t)}{R_{L}},
\end{aligned}
$$

Where:

C - DC circuit capacitor,

$R$ - load resistance.

The basic physical properties of the considered system can be found without the solution of differential equations $(2,3)$, considering only the established modes of operation.

In the steady state operation, the systems of equations $(2,3)$ are transformed to form:

$$
\begin{aligned}
& 0=U_{d}+r_{1} I_{d}-x_{1} I_{q}, \\
& E_{1}=U_{q}+r_{1} I_{q}+x_{1} I_{d}, \\
& U_{d}=\frac{m U_{d c}}{2} \sin \varphi_{m}, \\
& U_{q}=\frac{m U_{d c}}{2} \cos \varphi_{m} . \\
& \frac{3}{2} E_{q} I_{q}=U_{d c} I_{L}+\frac{3}{2} r_{1}\left(I_{d}^{2}+I_{q}^{2}\right), \\
& I_{L}=\frac{U_{d c}}{R_{L}},
\end{aligned}
$$

Equations $(4,5)$ allow to calculate output voltage AR when the modulation factor $m$ and modulation phase $\varphi_{m}$ change. 


\section{ELECTROMAGNETIC AND ENERGY CHARACTERISTICS OF THE SHAFT GENERATOR WITH PMSG / Elektromagnetske i energetske značajke osovinskog generatora s PMSG-om}

In the mathematical description $(4,5)$ the vectors of state variables are used in a vector diagram to estimate the electromagnetic and energy properties of PMSG. When constructing a vector diagram according to equation $(4,5)$, electromagnetic processes in the PMSG are considered in the system of rotating coordinates $(d, q)$ related to the construction of the machine $[9,12,16]$, and electromagnetic processes in the AR are considered in the rotating coordinate system $x, y$ related to the voltage and current in the load. In this case, the flow vector $\bar{\psi}_{0}$ is combined with the zero state of the rotor position sensor (RPS) and is directed along the real axis (d) rotating at the speed of the coordinate system. In this case, the EMF rotation $\bar{E}_{1}=j \bar{\psi}_{0}$ ù is 90 degrees ahead of the $\bar{\psi}_{0}$ and will be directed along the imaginary $q$-axis. Therefore, when building a vector diagram, it is necessary to take into account the fact that the direction of one of the state vectors (voltage or current) is determined by the initial installation of DPR. Vector diagram reflects the physical operation of PMSG and allows you to qualitatively assess the properties of the generator, which depends on both the parameters of the machine itself and the way of construction and the algorithm of active rectifier control.

In the general case for control of the current source the vector diagram of PMSG in the generator mode is shown in Figure 3.

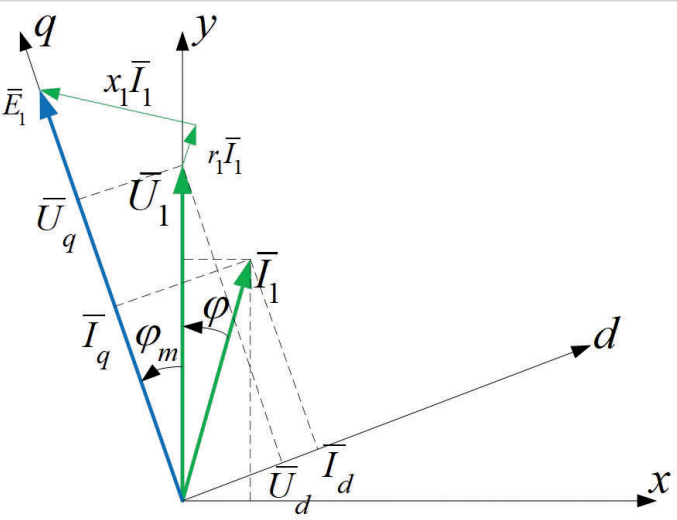

Figure 3 Vector diagram of the generator with PMSG Slika 3. Vektorski dijagram generatora s PMSG-om
The main static characteristic, which represents the dependence of the output voltage AR on the modulation factor $\mathrm{m}$ and phase of modulation $\varphi_{m}$ is determined on the basis of the joint solution of equations $(4,5)$.

$$
U_{d c}=\frac{\frac{3}{4} m E_{1} \frac{R_{L}}{z^{2}}\left(r_{1} \cos \varphi_{m}+x_{1} \sin \varphi_{m}\right)}{1+\frac{3}{8} m^{2} \frac{r_{1} R_{L}}{z_{1}^{2}}}=\frac{\frac{3}{4} p \omega_{m} \Psi_{0} \frac{R}{z^{2}}\left(r \cos \varphi_{m}+x \sin \varphi_{m}\right)}{1+\frac{3}{8} m^{2} \frac{r_{1} R_{L}}{z_{1}^{2}}}
$$

where $R_{L}$ - load resistance, $z_{1}=\sqrt{r_{1}^{2}+x_{1}^{2}}$ - full resistance of PMSG and $A R$ on the $A C$ side.

Figure 4 shows the dependencies of output voltage AR on the modulation factor and modulation phase for the two speeds of the machine shaft $100 \mathrm{rad} / \mathrm{s}$ and $150 \mathrm{rad} / \mathrm{s}$. Projections of these surfaces on the main plane are lines of constant voltage at the output of the AR.

The areas of allowable values of modulation factor and phase of modulation lie above the specified values of the output voltage AR.

If the power semiconductor converter uses current control $[2,8]$, the control signals are currents $I_{d}^{*}$ and $I_{q}^{*}$ the longitudinal and transverse components of the voltage are determined from equations:

$$
\begin{aligned}
& U_{\mathrm{d}}=-r_{1} I_{d}^{*}+x_{1} I_{q}^{*}, \\
& U_{\mathrm{q}}=-r_{1} I_{q}^{*}-x_{1} I_{d}^{*}+\psi_{0} \omega .
\end{aligned}
$$

Energy characteristics of PMSG are calculated by equations:

$$
\begin{aligned}
& P_{1}=\frac{3}{2}\left(U_{d} I_{d}^{*}+U_{q} I_{q}^{*}\right), \\
& Q_{1}=\frac{3}{2}\left(U_{q} I_{d}^{*}-U_{d} I_{q}^{*}\right), \\
& P_{G}=\frac{3}{2} E_{q} I_{q}^{*}, Q_{G}=-\frac{3}{2} E_{q} I_{d}^{*},
\end{aligned}
$$

Figure 5 shows the results of calculation of energy characteristics, which are presented by the dependencies of active and reactive power at the PMSG output on control signals. Power surface projections on the main plane represent the dependencies between these control signals, at which the power is constant.

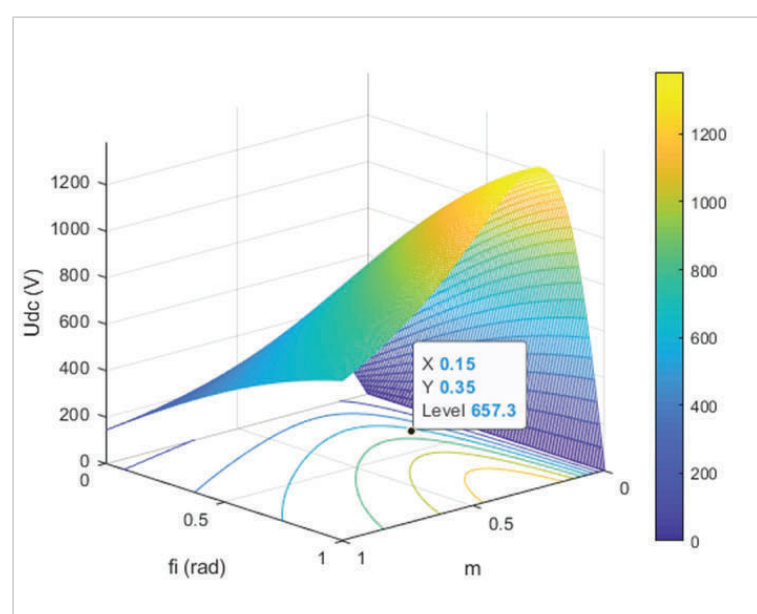

a)

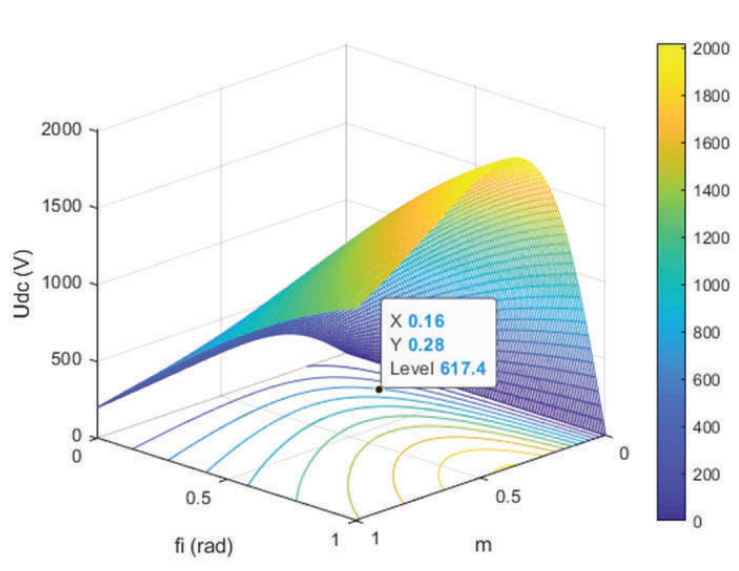

b)

Figure 4 Output voltage AR on the modulation factor $(\mathrm{m})$ and modulation phase (fi) for the two speeds of the machine shaft (a) $100 \mathrm{rad} / \mathrm{s}$ and $150 \mathrm{rad} / \mathrm{s}(\mathrm{b})$.

Slika 4. Izlazni napon AR na faktor modulacije (m) i fazu modulacije (fi) za dvije brzine osovine stroja (a) $100 \mathrm{rad} / \mathrm{s}$ i $150 \mathrm{rad} / \mathrm{s}$ (b). 


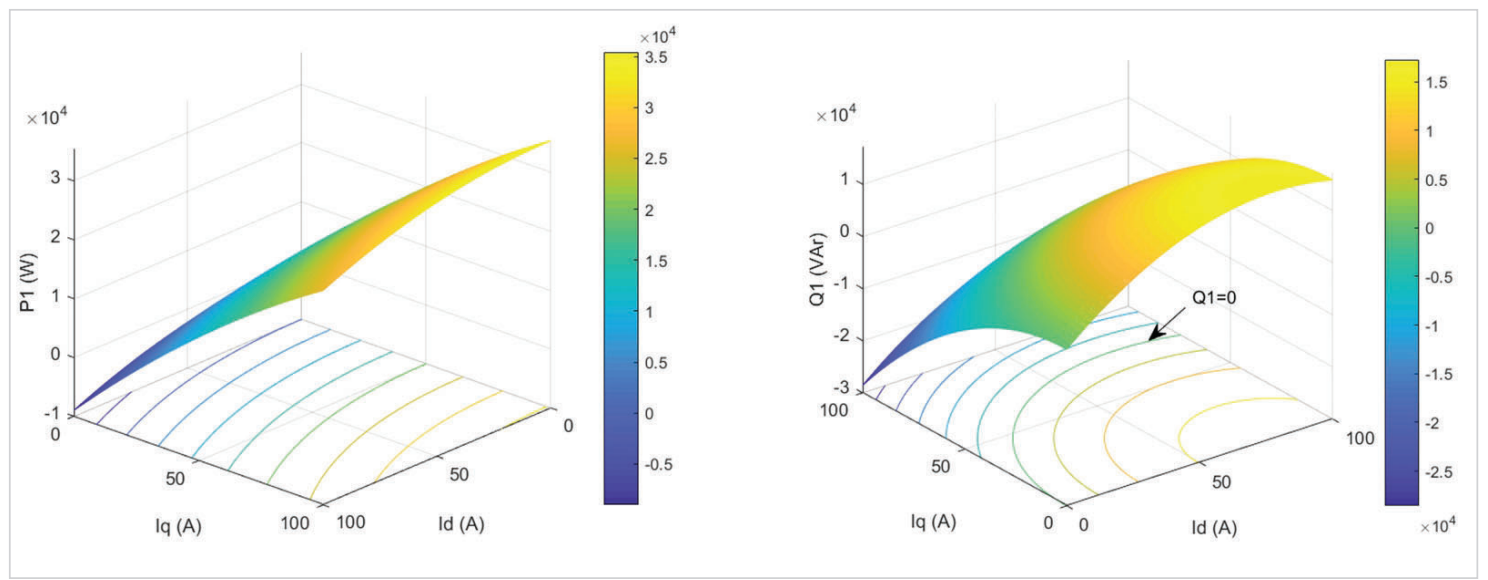

Figure 5 Energy characteristics of the generator with current control. Slika 5. Energetske značajke generatora s regulacijom struje.

The received power characteristics of the current control of PMSG allow estimating of properties of the system which are reduced to the following:

- the active power in the PMSG load in the generator mode depends mainly on the current component $I_{q}$ and insignificantly on the component $I_{d}$,

- the reactive power in the PMSG load is comparable with the active power, which causes an increase in the total current and losses in semiconductor AR devices and PMSG windings,

in order to maintain zero reactive power in the PMSG load, it is necessary to maintain a certain nonlinear dependence between $I_{q}$ and $I_{d}$,

- the range of control signal change at the zero reactive power in the PMSG load for the selected machine is limited by the value $I_{q} \leq 70 \mathrm{~A}$,

- at control only on the active component $\left(I_{d}=0\right)$ the reactive power in the whole range of change $I_{q}$ remains negative. In this case, the AR for the PMSG is an active capacitive load.

\section{ENERGY CHARACTERISTICS OF AN OPTIMIZED SHAFT GENERATOR WITH PMSG / Energetske značajke optimiziranog osovinskog generatora s PMSG-om}

For the optimal control of the AR, the voltage and current at the PMSG output coincide in the phase (Figure 6).

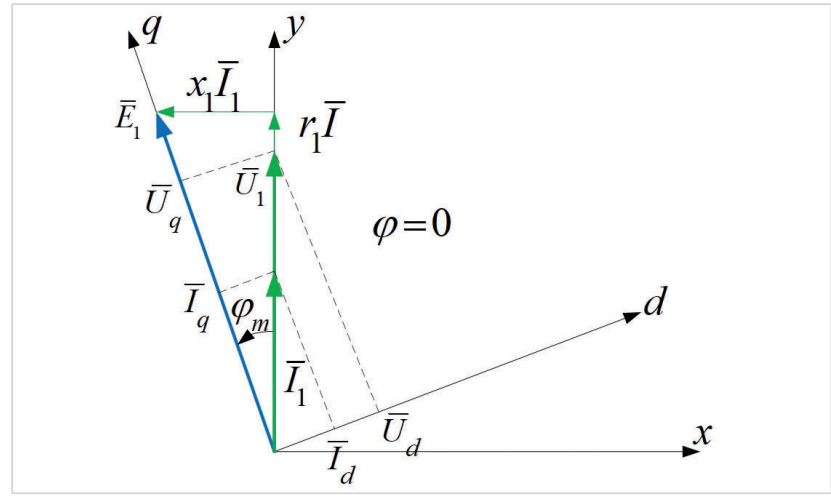

Figure 6 Vector diagrams in the system at zero reactive power in the PMSG load.

Slika 6. Vektorski dijagrami u sustavu s nula jalove snage u PMSG opterećenju.

Then from geometrical constructions (Figure 6), it is possible to define longitudinal and transverse components of currents at which reactive power at the PMSG output is equal to zero.

$$
\begin{aligned}
& I_{d}^{*}=\frac{\mathrm{p} \omega_{m} \psi_{0}}{x_{1}} \sin ^{2} \varphi_{m}, \\
& I_{q}^{*}=\frac{\mathrm{p} \omega_{m} \psi_{0}}{x_{1}} \sin \varphi_{m} \cos \varphi_{m}
\end{aligned}
$$

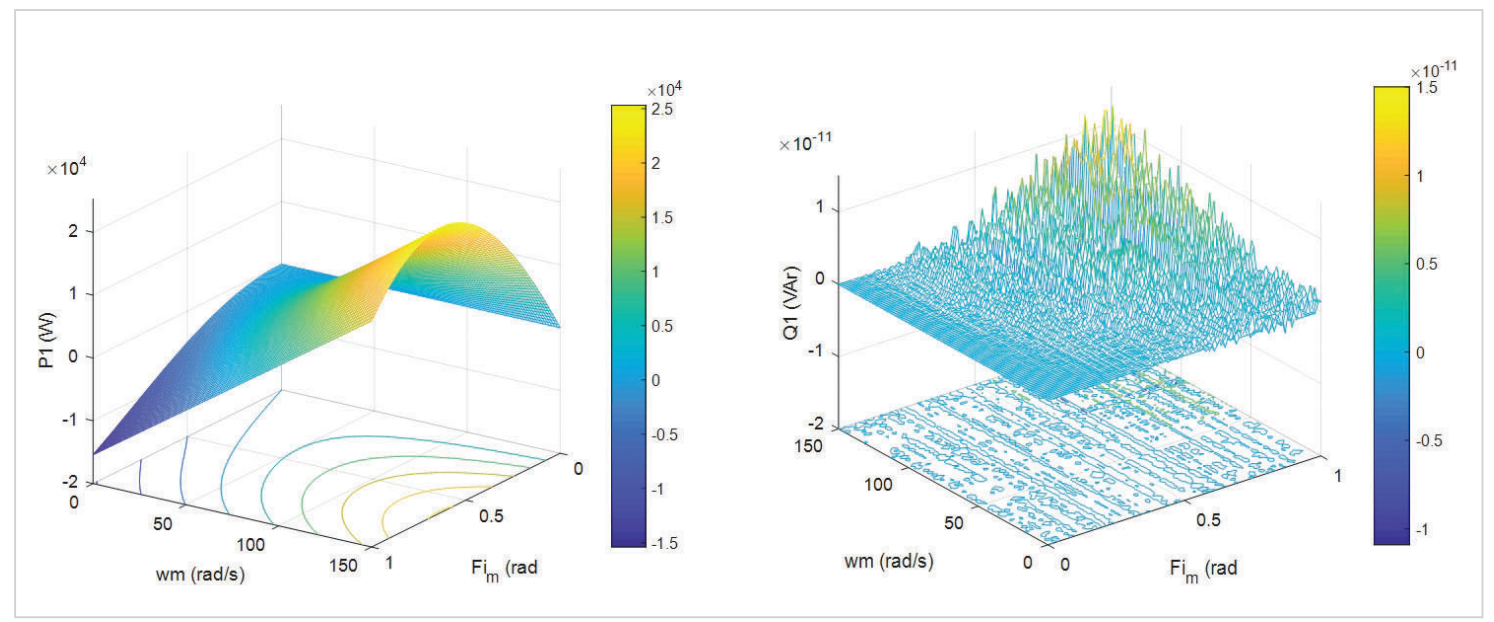

Figure 7 Optimized energy characteristics of the generator Slika 7. Optimizirane energetske značajke generatora 
Calculation of energy characteristics of the generator at such control is carried out by equations $(7,8,9)$.

Calculated and constructed energy characteristics of the system are presented in Figure 6, from which it follows that:

- while maintaining the dependence (9), the reactive power at the PMSG output is equal to zero in the whole range of control signals change;

- while maintaining the dependence (9), active power at the PMSG output can be maintained constant at essentially nonlinear dependence between modulation phase and shaft speed of the machine;

- with the increase of power at the PMSG output, the permissible range of changes in the control signals is reduced.

\section{MODEL STUDY OF PSMG / Studija modela za PSMG}

Experimental study of the closed-loop generator control system was carried out in Matlab-Simulink environment. The model of the generator with PMSG is shown in Figure 8. In the structure under consideration, the internal combustion engine is controlled by a speed regulator. In this mode, the speed of the PMSG shaft is specified and the main requirement to its electrical part is to maintain a constant voltage in the DC link when changing the electrical load. Voltage stabilization is carried out in a classical system control with a PID regulator.

The signal from the output of the PID regulator is fed to the functional converters (Fcn6, Fcn7 - Figure 8). In converters the reference currents according to the equation are calculated(9). Modulation phase is defined in block Fon10 (Figure 8) by the equation.

$$
\varphi_{m}=\operatorname{arctg} \frac{U_{d}}{U_{q}}
$$

The system with independent current control, which is described by equation (4), and the system with optimized current control, described by equation (5), are compared. Figure 9 and Figure 10 show the results of modelling of both systems in transient and steady-state modes of operation of the generator set with PMSG.

In the steady-state mode of operation under load in the system with independent current control $\left(I_{d}^{*}=0, I_{q}^{*}=\right.$ var $)$ the reactive power of PMSG is approximately one third of the active power (Figure 9,a). In the optimized system (Figure 10,a), shortterm changes in reactive power are observed at the time of load shedding. In the steady-state mode this power is practically equal to zero. Electromagnetic processes in both systems are shown on the Figure 9,b, Figure 10,b , they are represented by currents in the stator of the machine, the load current in the DC link $\operatorname{AV}\left(I_{d c}\right)$ and the voltage in the DC link AV $\left(U_{d c}\right)$.

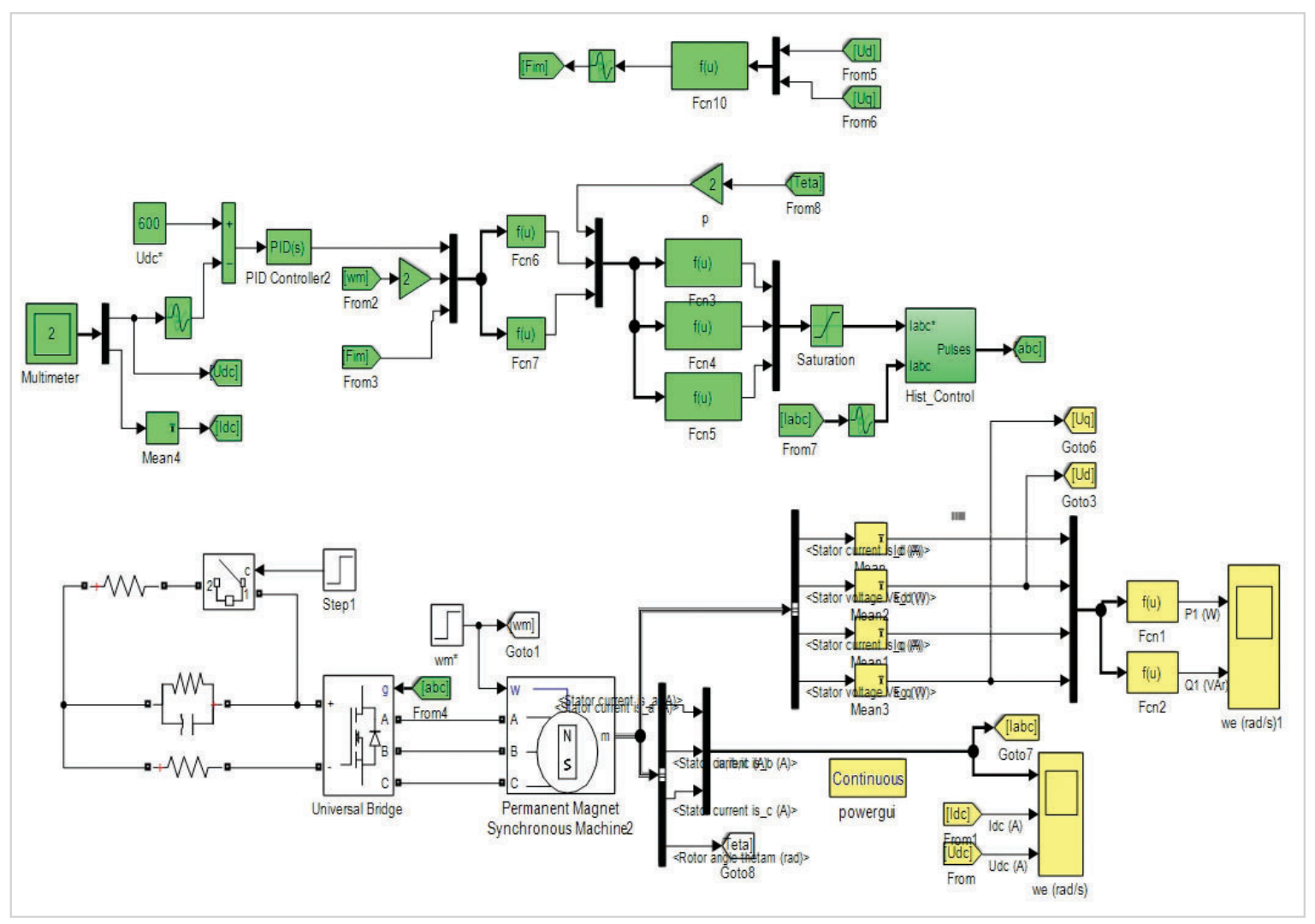

Figure 8 Model of the generator with PMSG Slika 8. Model generatora s PMSG-om 


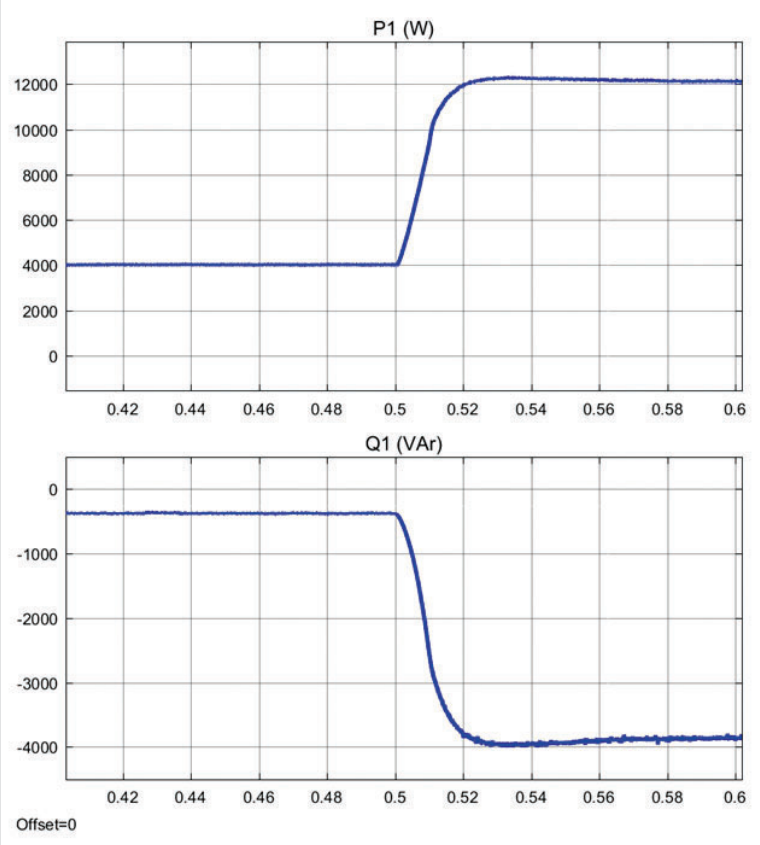

a)

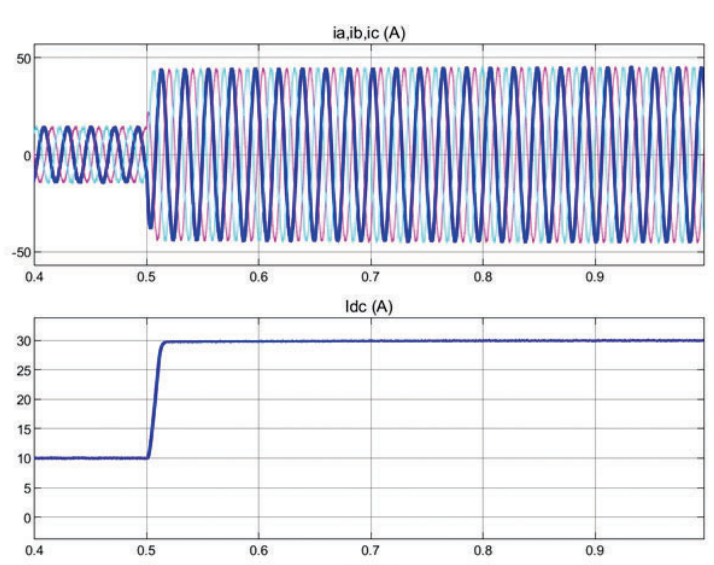

$\operatorname{Udc}(\mathrm{A})$

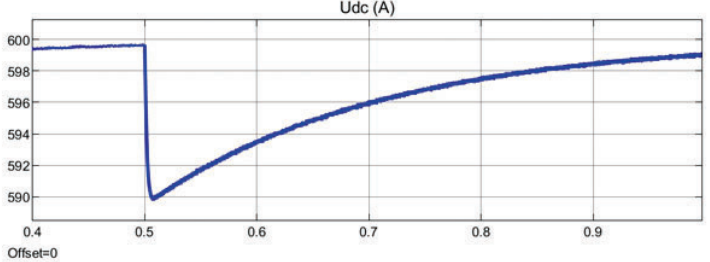

b)

Figure 9 Transition energetics (a) and electromagnetics (b) processes in an unoptimized system when changing the load Slika 9. Tranzicijski procesi energetike (a) i elektromagnetike (b) u neoptimiziranom sustavu pri promjeni opterećenja
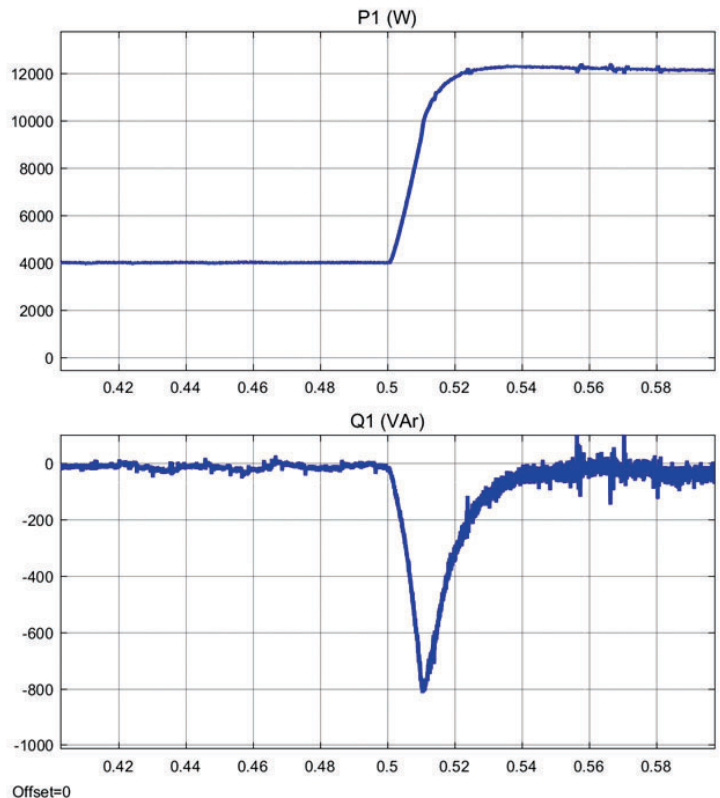
Offset $=0$

a)

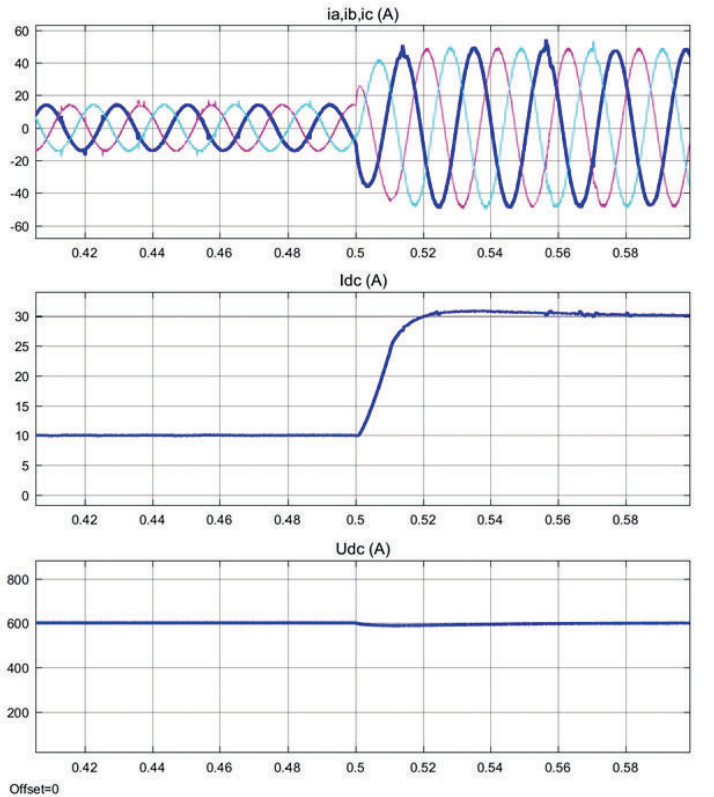

b)

Figure 10 Transition energetics (a) and electromagnetics (b) processes in optimized system when changing the load Slika 10. Tranzicijski procesi energetike (a) i elektromagnetike (b) u optimiziranom sustavu pri promjeni opterećenja

The processes presented on Figure 10 show that in the optimized system the change in the generator electrical load does not affect the voltage.

Curves (Figure 11, a, b) demonstrate energetics and electromagnetics processes in the optimized system with PMSG when changing the speed from 150 to $100 \mathrm{rad} / \mathrm{s}$ of generator shaft.

The results of the modeling show that the generator set with PMSG provides the basic requirements - to maintain a constant voltage at changing the current (power) in the load and changing the speed of rotation of the shaft. In addition, with the optimal control according to the equation (5), the reactive current in the machine is reduced to zero, which reduces the losses in the active resistances of the machine and the active rectifier.

\section{CONCLUSION / Zaključak}

The study of the electromagnetic and electromechanical properties in a steady state of the PMSG-AR system allowed assessing the performance of the SG system in the case of shaft speed and load change.

The proposed AR control allowed the optimization of the SG system by reducing the reactive power in the PMSGAR system. Reactive currents and, accordingly, losses in the 


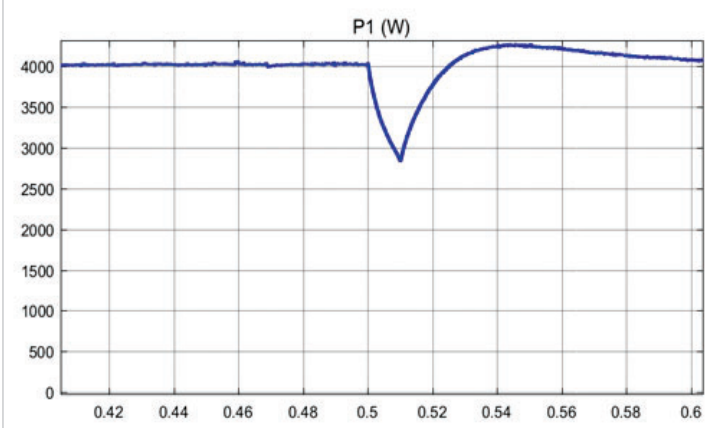

Q1 (VAr)

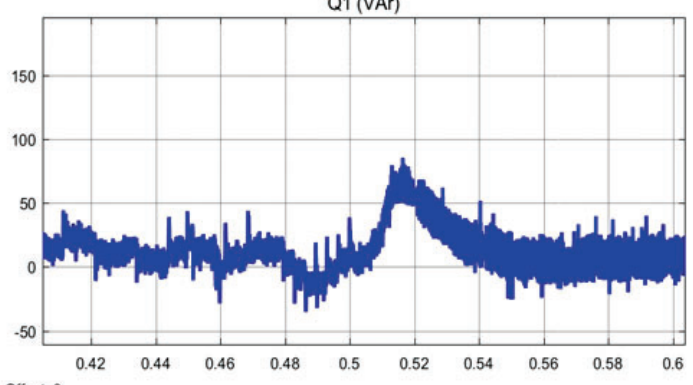
Offset $=0$

a)
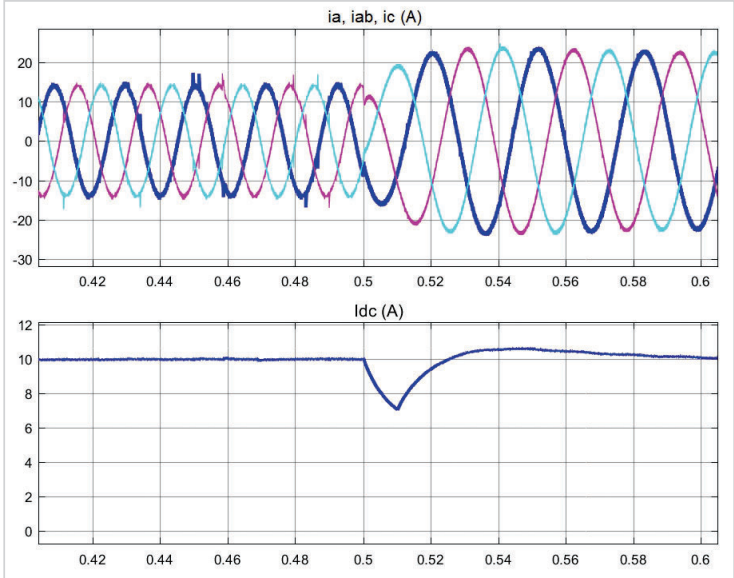

$\operatorname{Udc}(\mathrm{A})$

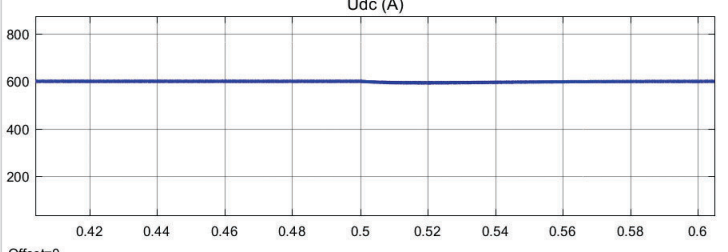

b)

Figure 11 Transition energetics (a) and electromagnetics (b) processes in an optimized system when changing the speed from 150 to $100 \mathrm{rad} / \mathrm{s}$ of generator shaft

Slika 11. Tranzicijski procesi energetike (a) i elektromagnetike (b) u optimiziranom sustavu pri promjeni brzine od $150 \mathrm{do} 100 \mathrm{rad} / \mathrm{s}$ osovine generatora

converter and the machine may be several times lower with a certain ratio between the amplitude and the phase of the voltage (current) on the AC side of the AR.

Optimization of energy properties of generating sets acquires special importance in the construction of powerful hybrid transport systems and systems with full electric propulsion. These systems have different, as compared in terms of power, sources of electrical energy operating on the total variable load. Examples of such objects are land-based, sea, river and air transport, and examples of such sources of electrical energy - diesel generators, shaft generators, steam and turbo generators, batteries, supercapacitors, etc.

\section{REFERENCES / Literatura}

[1] Ahmed, A., Haider, A., Van Hertem, D., Zhang, I. and H. Nee, P., Prospects and challenges of future HVDC Super Grids with modular multilevel converters, Proceedings of the 2011 14th European Conference on Power Electronics and Applications, 30 Aug - 1 Sep 2011, pp. 1-10, Birmingham, United Kingdom, (2011).

[2] Brodovski, V. N., Ivanov E. S. Drives with frequency current control, "Energy", Moscow, Russia 1974.

[3] Bulgakov, A.A., New Theory of Controlled Rectifiers; "Science", Moscow, Russia, 1970; pp. 326.

[4] Chan, T., and Lai, L. "Permanent-Magnet Machines for Distributed Power Generation: A Review," IEEE Power Engineering Society General Meeting, Conference Location: Tampa, FL, Added to IEEE Xplore: 23 July 2007, https:// doi.org/10.1109/pes.2007.385575

[5] Fazeli, S.M., Jovcic, D., Lin, W.: Distributed Control for LCL DC Hub Enabling Reliable Energy Transfer in Future DC Grids, Published in: 11th IET International Conference on AC and DC Power Transmission, Birmingham, UK, 2015, https://doi.org/10.1049/cp.2015.0035

[6] German-Galkin, S.: MATLAB SCHOOL. Virtual laboratory for power electronics and electromechanical devices in Matlab+Simulink software. Lesson 26: Optimization of energetic properties of mechatronic system by means of electric machine with power electronic, Magazine „Power electronics" Vol. 3, No 72, pp. 68-75, 2018, (ISSN 2079-9322).

[7] German-Galkin S., Tarnapowicz D., Tomasov V. S., "The Use of Topology of IHBI Inverters in Parallel Operation of Ship Generating Sets With PMSG Generators," New Trends in Production Engineering, Volume 1: Issue 1, $10 \mathrm{Dec}$ 2018, pp.309-315, https://doi.org/10.2478/ntpe-2018-0038
[8] German-Galkin, S., Tarnapowicz, D., Matuszak, Z., Jaskiewicz, M., Optimization to Limit the Effects of Underloaded Generator Sets in Stand-Alone Hybrid Ship Grids, Energies 2020, 13(3), 708; doi.org/10.3390/en13030708 - 2020 https://doi.org/10.3390/en13030708

[9] Gorev, A. A.: Transient processes of synchronous machine, Leningrad Moscow: State Energy Publishing House (Gosenergoizdat), pp. 552, 1950

[10] [10] Hu, J., Stieneker, M., Joebges, P., Doncker, R.: Intelligent DC-DC Converter Based Substations Enable Breakerless MVDC Grids, Published in: 2018 IEEE Electronic Power Grid (eGrid), Charleston, SC, USA, DOI: 10.1109/ eGRID.2018.8598689

[11] Jamieson, P. Innovation in wind turbine design. 2nd Edition, Publication A John Wiley \& Sons, Ltd.,2018, ISBN: 978-1-119-13790-0

[12] Kovacs, K.P., Racz, I.: Transient processes in alternating current machines, Transiente Vorgänge in Wechselstrommaschinen. Verlag der Ungar. Budapest: Akad.der Wissenschaften, 1959.

[13] [13] López-Ortiz, E., N., Campos-Gaona, D., and Moreno-Goytia, E., L. "Modelling of a wind turbine with permanent magnet synchronous generator," IEEE 2012 North American Power Symposium (NAPS), Added to IEEE Xplore: 22 October 2012. https://doi.org/10.1109/naps.2012.6336439

[14] Lu, S., Wang, L., Lo, T., Prokhorov, A.: Integration of Wind Power and Wave Power Generation Systems Using a DC Microgrid, Published in: IEEE Transactions on Industry Applications, Volume: 51 , Issue: 4 , July-Aug. 2015 https://doi.org/10.1109/tia.2014.2367102

[15] Ovchinnikov I. E. Permanent Magnet Synchronous Motors and drive on their basis. SPB, Corona - Century St. Petersburg, 2006, ISBN 5-7931-0344-9.

[16] Park, R. H.: Two-reaction Theory of Synchronous Machines-II", AIEE Transactions, vol. 52, June 1933.

[17] Rossa R., E. Krol, "Modern electric machines with permanent magnet., Przegląd Elektrotechniczny, Volume 84, Issue 12. 2008 pp. 12-17, ISSN: 0033-2097

[18] Sarigiannidis, A., Kladas, A., Chatzinikolaou, E., Patsios, C.: High efficiency Shaft Generator drive system design for Ro-Ro trailer-passenger ship application. IEEE International Conference on Electrical Systems for Aircraft, Railway, Ship Propulsion and Road Vehicles (ESARS) 2015, ISBN: 978-1-4799-7400-9, Print ISSN: 2165-9400, Date Added to IEEE Xplore: 07 May 2015 https://doi. org/10.1109/esars.2015.7101529

[19] Semken, R.S., and all, "Direct-drive permanent magnet generators for highpower wind turbines: benefits and limiting factors," Renewable Power Generation, IET , vol.6, no.1, pp.1-8, January 2012. https://doi.org/10.1049/ iet-rpg.2010.0191

[20] Tarnapowicz D., German Galkin S., Jarlaczyński J. Testing of a Prototype of a Two-Segment Low-Speed Generator with Permanent Magnet for a Lower-Power Wind Farm. International Conference on Information and Digital Technologies (IDT) 2019. IEEE ISBN 978-1-7281-1402-6. https://doi. org/10.1109/dt.2019.8813369 